\title{
AUSTRALIAN STRATIOVYIIDE.
}

\author{
By G. H. Hardy. \\ Platc VIII. \\ (Read 8th Junc, 1920.) \\ Fam. STRATIOMYIID X.
}

The species belonging to this family are easily recognised by a combination of two venational characters-ono is a short discal cell emitting veins, some of which do not as a rule reach the wing border, and the lower branch of the cubital fork running to or above the apex of the wing is ti,y etler. The antennx are of diverse forms, the third joirt of which may consist of as many as eight segments clearly defined, or all or many of these segments may be partly or completely fused. The abdomen consisting of from five to seven visible segments is often depressed.

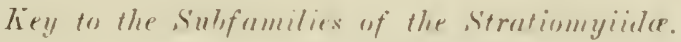

1. The abdomen with seven visible signents. BEMIDIN.R. The abdomen with five or siz visible segments. 2 .

2. The wings with three posterior veins. 3.

The wings with four postcrior veins. 4 .

3. Antenna with a short, usually bulbous, third joint which bears a hair-like arista. PacuYcistemins.

The antennæ elongate, ten-segmented, the tenth segment as long as the other nine together, ribbonlike, and more or lcss parallel sided. Lophatel.his.s.

4. 'The wings with the fourth posticicr cell rising from the cliscal cell, or at least touching it.

The wings with the fourth posterior cell rising from the second basal rell and not touching the discal cell.

5. The scutollum withont spines and tho last antennal segment elongate.

IIERMETIIN.S.

The scutellnm with spines and the last antemnal segment shert or moderately long.

CI.ITELLARIN.E.

6. Tho antennx with a throad-like arista. SARGIN.F

Tho antennæe without an arista, at most with a short blunt style.

STRATIOMYIINE.

C 


\section{Subfam. BERIDINE.}

S'ynomymy.-In the "Catalogus Dipterorum" Kertesz places Irmomiorphor as a synonym of the genus (hirmmyzu and suggests that Inopus is also a synonym of the same. The position of the Australian species placed under the genus Senomorpha is still uncertain, but they are allied to the genus ('hiromyzr", and the genus Inopus agrees better with the genus Metormin, and indeed may be synonymous with it.

White, in 1916, placed Trummoryllen as a synonym of

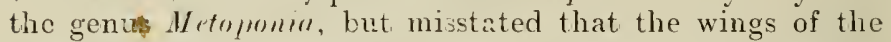
latter have four posterior veins. White's mistake eaused him to create the genus ('rypholseris for species with three posterior vcins, but the genotype is a male of Macquart's female type species of the genus $1 /$ rempmin. On this account, in the present paper. C'ryptuberis is placed as a synonym of the genus Mefopromin, and the genus. Fenomerthu is used for convenience for all species of Beridtince without scutellar spines and with four posterior veins present. The material to hand is not sufficient to form a better arrang ment.

\section{Ley to the cienere of the Beribline.}

1. The seutellum without spines.

The scutellum with spines.

2.

3.

2. The wings with three posterior veins.

The wings with four posterior veins.

3. The cyes bare.

The cyes hairy.

Ietopuniu. Ermomioriters.

4. The antennæ elongate, three tintes as long as the head; the wings without markings.

Yanthoberis.

The antenna moderately long: the wings marked with fuscons.

Teveraireta.

Genus Metoponia, Macquart.

Metopmir, Macquart, Dipt. Exot., suppl. 2, 1847, p. 28. It., Walker, List Dipt. B.M., v. suppl. 1, 1854, p. 112. Ir., Osten-Sacken, Berl. Ent. Zeit., xxvii., 1883, p. 297. Id., White, Proc. Roy. Soc. Tasm., 1914. p. 46 ; and 1916 , p. 260.

Cryptoleris, White, P.L.S. N.S.W., xli., 1916, p. 73.

Type-Metopmin rubricess, Macquart.

Charuters.-The speeies in this a... New Holland. receding face; the eyes contiguous in the male and widely separated in the female; the abdomen with seven visible 
segments and rather elongated in the female; the scutellum without spines and the whole insect devoid of strong hairs or bristles. The wings have three posterior veins, a reduced discal cell and the anal cell closed before the wing margin.

$$
\text { Key to the sipecies of Metopromitr. }
$$

1. The two basal joints of the antemix equal; a yellow brown species. prisca.

The first joint of the antennæ conspicuously longer than the sccond; a black, brown or reddish species and the fomale with a reddish head. rul,riceps.

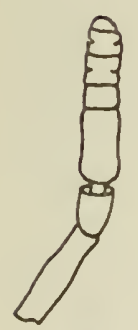

1

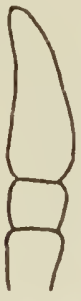

2
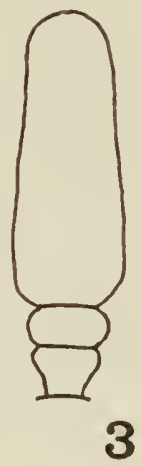

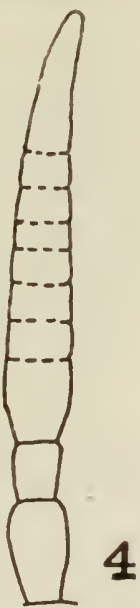

Irtopunie rubrireps, Macquart. Text fig. 1.

Metopunun rulirierps. Macquart. Dipt. Exot.. supnl. 2, 1847, p. 28, pl. i. fig. 4 ; and suppl. 3,1818, p. 15. II.. Walkcr, List Dipt. B.M., v. suppl. 1, 1854, p. 113. IIl. Osten-Sacken, Berl. Ent. Zeit., xxvii., 1883, p. 2J7. Id., White, Proc. Roy. Soc. Tasm., 1914, p. 46. Id., White. P.L.S. N.S.W., xli., 1916, p. 75 .

('hirmmina flavirapmt, Walker, Ins. Saund. Dipt., i., 1852, p. 163 .

C'ryptoleris herlessens, White, P.L.S. N.S.W., xli., 1916, p. 74, Text fig. 1.

Symonymy-Dr. E. W. Ferguson has a specimen named by White as Cryptulueris lerbescens. It was taken about the same time of the year and in the same locality as the type, and it agrecs in every respect with the male of $\boldsymbol{M}$. 
rubriceps, Macquart, clescribed below, and does not agree with the antennal proportions given by White. A critical study of White's description compared with a number of undescribed Beridince has led the writer to conclude that the description given by White is misleading, and therefore the above specimen determined by White is considered to be correctly identified.

Inupus despectu.*, Walker (Ins. Saund. Dipt.), from unknown locality may also be intended for the male of $\boldsymbol{M}$. rulirireps. Macquart, but the illustration with it does not. quite conform to this insect.

Description.-Male. The head is black or blackish brown; the eyes are contiguous; the sccond joint of the antennæ is about one quarter the length of the first, and the third joint is as long as the first and is segmented. The thorax, sutellum, and abdomen are blackish brown, and a golden yellow pubescence, very conspicuous in fresh specimens, covers a large area of the thoray dorsally, and extends on to the scutellum and abdomen; ventrally the abdomen has yellow and much shorter pubescence; the male genitalia is exposed. The legs are yellowish brown and the wings are similarly coloured.

Length.-Males, 5-6 mm.; females, 6-10 $\mathrm{mm}$.

Hat,.--New South Wales: Sydney, March and April, 1919, 30 males and 13 females, and November, 1919, 24 males and three females. Victoria: Melbourne, November and December, 1 male and 2 females taken by Mr. C. E. Cole. Tasmania: This locality is recorded by Macquart, but specimens are not represented from there in recent collections.

Note.-Specimens have been taken in copula during the spring and the autumn, and this places its sex relationship beyond dispute.

\section{Metoponia prisca, Walker.}

Chiromyza prisca, Walker, Ins. Saund. Dipt. i., 1852, p. 162 .

Strtus.-A blackish species with yellow pubescence is referred here with considerable doubt. Walker's description agrees with the species described below about as well as Chiromyza Aavicalut of the same author agrees with the previous species. Until the type is examined it is advisable to append Walker's name to this, the only species from Tasmania, the type locality, that conforms to the description in ally way.

Deseription.-Male. The cyes have scanty pubescence and are contiguous; the front consists of ocellar and 
BY G. H. HARDY.

antennal triangles, the former is black and the latter is covered with yellowish tomentum and pubescence; the antennæ are short, consisting of two equal basal joints, and tho third is as long as the two basal joints united; the face recedes and has yellow tomentum and lateral pubescence. The thorax and the base of the scutellum are black with the sloulder spots and apical margin of the scutellum yellowish, the latter markings extend on to the thorax; no other markings are perceptible; the pubescence is yellow and depressed. The abdomen is black-brown with vellow nubescence. The legs are vellowish, stained with black on the tibix and tarsi. The wings are light grey, a little ciarker along the anterior half.

Female. The head is black and the cyes are widcly separated; the antenna aro similar to those of the male. but the third joint is a little longer than the basal joints united. The thorax is black. similar to the male, but with the markings more extended and showing tendencics to approach these of Iemmorplin austmlis, Macquart describod below. The scutellum is ycllow. The abclomen is black with the apex of most of the scgments bordered conspiruously brown. The legs havo the base of the segments yellowish, otherwise they are much stained witl fuscous.

\section{Length.-Male 5-6 $\mathrm{mm}$. : female $10 \mathrm{~mm}$.}

Mab.-Tasmania: Cradle Mountain, 13 malrs and 10 females, January, 1917 ; Wynyard, 1 male, 2nd February. 1916 ; Mt. Wellington, I male, 9t lı January, 1919.

Fute.-The rescmblance of this species to Trmumorpha anstrelis, Macquart, is remarkable; few points other than that of venation can be found to scparate tlem.

\section{Genus Xexomolipis, Macquart.}

Ienmmerplin, Macquart, Dipt. Exot. i. 1, 1838, p. 193; and i. 2, 1839, p. 190.

Metrpmin, White (nec Macquart), P.L.S. N.S. IT., xli., 1916, p. 74.

Typo.- Semmorpher leptiformis, Marquart; Brazil.

Symonymy.-White mistook the characters of the genus Mrtopmin, stating that it has four posterior veins, and thus he treated. Irnmmrpher as a synonym of it.

('Hararers-Until the study of the species of the world is undertaken it seems advisable to keep. Venumorplia as a generic name for the Australian species of Brriliner with four posterior veins and without scrutcllar spines. 
key to the species of Ienomorpha.

1. A non-metallic species with the antennæ short, the third joint short.

allstralis.

A species with a metallic thorax and the antennæ with the two basal joints minute, the third joint long, in proportion, and swollen. yrandicornis, sp. nou.

Ienomorpha ausfrulis, Macquart.

Text fig. 2.

Tenomorplla anstralis, Macquart, Dipt. Exot., suppl. 4, 1850, p. 54, pl. iii., fig. 7. Il., Williston, Trans. Ent. Soc. Phil., ₹v., 1888, p. 244.

Metopunia anstratix, White, P.L.S. N.S.IV., vli., 1916, p. 75.

' Chiromuz" rivinn. Bigot, Ann. Soc. Ent. France (5), ix., 1879, p. 200.

? Metopmin ricinn, Kertesz, Cat. Dipt. iii., 1908, p. 145.

S'ynm!ymy.-Macquart's I. "rnstrolis, described from the East Coast of Australia, and Bigot's C. virma, queried from Austraiia, may belong to tho same species. Until the types are evamined it will be impossible to detcmnino if this is the case, and indeed Bigot's species may belong to quite a different genus.

The species described bolow is probably correctly identified and is the only form obtained in numbers and in sufficicntly good conditicn to warrant a description. There seem to be a number of specimens belonging to this: genus, but most of them arc represented by specimen's which are inferior in condition, and may ultimately prove not to be distinct.

Descrifirn.-Male. Although black, a covering of yellowish depressed pubescence gives this insect the appearance of being greyish. The eyes have scanty yellowish pubcsconce; the front is lincar and widens above the antenns and at the ocelli into triangular areas; the pubescence on tho ocellar triangle is black and on the antennal trianglo ycllow; the antennæ are yellow, stained more or less with black on the two basal joints, and the third joint is as long as the two basal joints together; the proboscis is yellow; the face is very leceding and has sparse whitish pubseccnce at the sides, and is covered with light grey tomontum which extends on to the frontal triangle. The tholax above has two faint reddich brown stripes which widen anteriorly, merge into two large shoulder spots and converge towards the scutellum, near which they disappeax, the pubeseence of the dorsum is yellowish and that of tha 
venter whitish. The scutcllum is black and has ycllow pubescence. Other but indistinct markings are prescnt on tho thorax and scutellum, and they appear to be remains of lateral thoracic stripes which extend on to the scutellum. The abdomen has the first segment inconspicuously margined apically with reddish brown, and the genitalia is black but more or less tipped with reddish brown; the pubscence is mor or less depressed, yellow, and with lighter and darker pubescence in places. Tho legs are brownish at the kasc and aper of the segments, and have vellowish pubcsconce. The wings are light grey and the lialter:s are yellow.

Female. Black with the pubescence mostly depressed and yellow. The cyes are widely separated and have scattercel pubesecnce; the fornt has ycllowish tomentum and mostly brownish pubes nce : it has also a decp median furrow on cach side of which, half-way betwecn the ocelli and antenne. there is a prominence with yellew pubescence. Tha antennx are reddish and ar on! very slightly stained black on the basal signents which have black hair: the length of the third joint is cqual to that of the two hasal joints unitad. "The proboscis is recidi-h and the receding face has vellow tomentuil and hairs. The theras has light shoulder spots from which run is pair of median stripes and a pair of lat ral stripes: the median stripes berme morr or less fused fowarde the scutollum, but the darker int real sepalating thum is still traceable; the lateral stripes meet the median and mu nu to the sutellum, whic!l is o:h rwis brewn with a black apical tip. Tho abdomen is similarly coloured to that of the male and most of the segments have an incon-picuous apical bown margin, and th apiral segments are mult attenuated. The legs luave the basal half of the segnents yzllowish. The wings and haltres are as in the male.

Irngth...-Male, $10 \mathrm{~mm}$; female, $13-1.5 \mathrm{~mm}$.

$H a$ \%.- Victoria: Cisbcrne, jo males and 4 females, collected by G. Ivell.

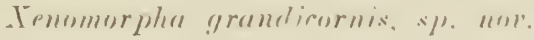

Text fig. ?.

Doseriffirn.- In general appearance this specics is similar to Affina incisuralis, Macquart. The antenna will distinguish it from any other l3eridiun known.

Male. The head is black and the cyes are widely separated and pubescent; the front is shining and lias black pubescence and about half-way between the antenna and tho ocelli there is a transverse impression from which 
run two parallel grooves to the ocelli and one median groove to the base of the antenim. The antennæ have the first two joints shcrt, small and equal, and the third joint is about four times as long as the two basal joints united, much swollen, cylindrical but slightly tapering apically, without segments, velvety black and bare of hairs. The face dees not recede as in $X$. australis, and has black hairs. The thorax and scutellum aro metallic blue and have black pubescence; on the shoulders and behind the wings there are yellowish markings. The abdomen is black with black pubescence, and the genitalia is reddish. The legs have the apex of the femora, and the baso and apex of the tibix yellowish red; the first tarsal joints are more or less red. The wings ar'e greyish.

Lenyth.-Male $7 \mathrm{~mm}$.

Hah.-Tasmania: Cradle Mountain (Pencil Pins: Creek?), one male taken on the 17th January, 1917.

\section{Genus Actina, Meigen.}

Actinu, Meigen, Klassif i., 1804, p. 116. Id., White, Pros. Roy. Soc. Tasm., 1914, p. 49. Id., White, P.L.S. N.S.W., xli., 1916, p. 77 .

Tvpo._Astima nitens, Latrielle. ... ... Europe.

Churncters. - The eyes are hairy and widely separated in both sexes; the scutellum lias four spines; the abdomen consists of scven visible segments; the wings contain four posterior veins all issuing from the discal cell, and the anal cell is closed before the wing margin.

$$
\text { kiey to the species of Actinu. }
$$

1. The two basal joints of the antennæ about equal.

victorice.

The first antennal jcint about twice the length of the second.

2. The scutellar spines always partly yellow at least; a species verv variable in size. incisuralis.

The scutellar spines always entirely metallic green; a very small species.

costata.

The character used for $A$. victorice, Hill, in the above key is taken from the description of that species.

Actina incisuralis, Macquart.

Beris ancisurulis, Macquart, Dipt. Erot., suppl. 2, 1847, p. 28; and suppl. 4, 1850, p. 42. Idl., Walker, List i)ipt. B.M. v. suppl. 1, 1854, p. 12 . 
Beris fil, fulpix, Macquart, Dipt. Exot., suppll. 4, 1850, p. 41, Pl. iii., fig. 2, 1850.

Artinu incisuralis, White, Proc. Rov. Soc. Tasm., 1914, p. 50. Id., White, P.I.S. N.S.W., yli., 1916, 1). 77.

"Brris fuscifntris. Macquart, Dipt. Exot., smppl. 4, 1850 , p. 42. I'l., Whitc, Proc. Rov. Soc. Tasm., 1914, p. 49. Id., White, P.L.S. N.S.IV., yli., 1916, p. 97.

?Beris nitiliturne, Macquart, Dipt. Exot., suppl. 4, 1850, p. 41, Pl. iii., fig. 3. I1., Whitr, Proc. Roy. Soc. Tasm., 1914, p. 49. I,l., White, P.L.S. N.S.W., xli., 1916,1 , 97.

Symunymy.-It is possible that Beris fuscimntrix and 13. nitidituritr, both flescribed by Macyuart. may belong hero; it will be noted that the reference to a figure given by Macquart under the former does not belong to that species but to sifrutimm!yin maxutn.

I/al,-Specimens have been cramined from Queensland, New South Irales, South Australua, Western Australia, and Tasmania. The specics has also been recorded from Victoria.

\section{Artimer restritu, White.}

Arfimu restufu. White, Proc. Rov. Soc. Tasm., 1914, 1). 51. Ir., White, P.L.S. N.S.IV.. xli., 1916, p. TT.

IIah.--This specics is ouly known from Tasmania, and it can be taken in quantitie's on Mt. W'ellington, about 2,000 ft.

$$
\text { Artinn resterier, Hill. }
$$

Actime returis, Hill, P.L.S. N.s. IT., xliv. (2), 1919, p. 450, figs. 1 a-c.

Status.-From the rescription this species apuears morc or less similar to A. imsinurulis, White. but the basal joints of the antenna are described as about equal in kength.

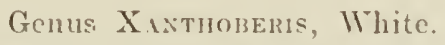

Santholieris, White, P.L.S. N.S.W., yli., 1916, p. Ti.

Type.- Tumtholeris siliaren. White.

..... New Sonth ITales.

Tantholueris silimen, White.

Irentholueris siliaren, White, P'I.S. N.S.WV., rli., 1916. p. 76 , text fig. 2 . 
Genus Neoexaireta, Osten-Sacken.

Diphysen, Macquart, Dipt. Exot. i. 1, 1838, p. 172 (preoccupied). Id., Walker, List Dipt. B.M., v. suppl. 1, p. 6.

Eraireta, Schiner, Verh. z.-b. Ges. Wien, xvii., 1867, p. 309 (preoccupied).

Teoexnireta, Osten-Sacken, Cat. Dipt. N. America, Edit. 2, 1878, p. 44. Irl., Enderlein, Zcol. Anzeiger, xlii., 1913, p. 552, figs. 17-19. Id., White, Proc. Roy. Soc. Tasm. 1914 , p. 48. It., White, P.L.S. N.S.W., xli., 1916, p. 78.

Venexuereta, Kertesz, Cat. Dipt., iii., 1908, p. 131.

Type.-Tylophayus spiniger, Wiedemann, ...... Port Jackson.

Ementments.-Enderlein described this gemus, after Macquart's figures, as having the radial vein (his r2-3) branching from the cubital (his $r$ main stem) beyond the median cross vein, but Australian spocimens liave tho radial vein branching interstatial with the median cross vein. Macquart's figures, and hence Enderlein's, show the scutellar spines to be conspicuously curved instead of straight or slightly curved and the antennæ differ considerably.

Charncters.-The eyes are bare and separated in both soxes; the antennæ are moderately long, the third joint. consisting of eight segments; the scutellum contains four soines; the abdomen consists of seven visible segments; the wings contain four posterior veins, the third of which does not reach the wing margin, and they all branch from the discoidal cell; also the wings are much marked with fuscous.

Tenexaireta spinigern, Wiedemann.

Text fig. 4.

Tylophagus spiniger, Wiedemann, Auss. Zweifl, ii., 1830, p. 618 .

Jiphyss spiniger. Macquart, Dipt. Exot. i. 1, 1830, p. 172. Iıl, Walke1, List. Dipt. B.M., iv., 1849, p. 1152.

Beris spinigera, Loew, Stett. Ent. Zeit., vii., 1846, p. 306. Sargus spinigera. Kirby, Ann. Mag. Nat. Hist. (5) xiii., 1884 , p. 457.

Tenernireta spinigera. Froggatt, Australian Insects, 1907, p. 293. Id., White, Proc. Roy. Soc. Tasm., 1914, p. 48. Id., White, P.L.S. N.S.W., xli., 1916, p. 78. Id., Hardy, Proc. Roy. Soc. Tasm., 1917, p. 63. 
Beris allimarulata, Walker, List Dipt. B.M. i., 1848, p. 126.

Beris servillei, Macquart, Dipt. Exot. i. 1. 1838, p. 172, Pl. xxi., fig. 1 ; and suppl. 1, 1846, p. 47.

(For further references sse Kertesz. Cat. Dipt. iii., 1908, p. 132.)

Hab.-A verv common species which has been recorded from Queensland, New South Wales, Victoria, and Tasmania, and also from some of the Pacific Islands.

\section{Subfam. Pachygasterix.e.}

('hornoters.-The Australian species of this subfamily have short antennx, the third joint of which is swollen, formed with a number of compact segments, and has a hairliko arista; the abdomen is formed with five visible segments, and the wings contain three posterior veins.

The four genera so far known to occur in Australia differ in the form of the scutellum which is normal and without spines in l'urhy!gaster, is produced into a spino in Lonchergater, has four spines in Firrol, and has many spines in $\mathrm{H}$ allenert.

\section{Genus Pachygaster, Meigen.}

I'uchyunster, Meigen, Ill. Mag. f. Ins., ii., 1803, p. 266. Id., White. P.L.S. N.S.W.. xli., 1916, p. 96.

(For synonymy see Kertesz, Cat. I)ipt. iii., 1908, p. 9.) Type-_. Yemotelus ater, Panz. ... ... ... Europe.

Churerters.-The antennx are three jointed, and tho third joint is bulbous and consists of several much compressed sngments terminating in a long arista; the scutellum is without snincs; the wings contain three posterior veins which issue from the discal cell.

Vofe.-White has a Tasmanian specimen of this renus in his collection, but he considered it to be a Lonchegaster witn the spines broken or deformed; this specimen should now be in the British Museum, and probably belongs to the species describad belcw. Later White recorded the genus from Victoria, but did not describe the species. Another species is represented by a specimen in the Macleay Museum from Mt. Kembla. New South Wales, but until further material is to hand it is not advisable to describe this or the many other new diptera in this old collection, most of which dates back fifty years and more.

The species described here is named after the late Arthur White. 
Pachygaster sp., Hardy, Proe. Roy. Soc. Tasm., 1917, p. 63.

? Pachygaster sp., White, P.L.S. N.S.W., xli., 1916, p. 97. Description.-Female. Black; the antennæ are reddish; the femora and tibix are reddish, but are stained darker in parts; the tarsi are yollow.

The front is shining and a little punetate; two more or less parallel depressions contain the unevenly distributed punctures, and run from the ocellar tuberele towards the antennæ, ending at a deeper median depression situated a little before the antennæ. The eyes are bare. The thorax, seutellum, and abdomen are evenly and densely punctate dorsally, and the punctures are unovenly dense ventrally; all the punetures are small. The pubeseenee is silvery around the antennæ and mouth, elsewhere it is golden yellow; some very inconspicuous black pubeseence can be seen on the front and elsewhere. The wings are hyaline and the veins are reddish and dusky yellowish. The halteres are yellow with blaek apiees.

The male is similar to the female, but is more slender in build; the eyes are apprcximate, and the punctures on the body appear a little less uniformly and densely distributed; the legs are pale yellow, and the femora are stained with fuscous; the halteres are pale yellow.

Variatim.-A female from Dunalley has the legs similar to those of the male.

Length.-Male, $4 \mathrm{~mm}$; female, $3 \frac{1}{1}-4 \frac{1}{2} \mathrm{~mm}$.

Type,-The holotype $q$ was taken at Hobart on the 26th January. 1917, the allotype of came from the same locality on the 29th December, 1917 ; both theso speeimens are in the Australian Museum. Two female paratypes are from Hobart on the 22nd January, 1916, and Dunalley 29th January, 1918, respeetively. In all there are ono male and three females taken in and around dwellings, three in the centre of Hobart and one in a farmhouse at Dunalley.

$H a b$.- Tasmania. The speeimen reeorded by White may belong to this species. The flight is similar to that of species belonging to the genus Odontomyir.

Genus Lonchegaster, White.

Lonchegaster, White, Proc. Roy. Soc. Tasm., 1914, p. 61. Id., White, P.L.S. N.S.W., xli., 1916, p. 97. Type.-Lonchegaster armata, White. ... ... Tasmania. 
Characters.-The eyes are contiguous in the male and separate in the fomale; the scutellum is produced into a spine; and the wings contain three postcrior veins. The genus differs from the Platynini to which group it otherwise bclongs according to Endorlein's keys (Zool. Anz., 1914), by thic contiguous eyes of the male.

\section{Lomblergaster armata, White.}

Limuelu'guster "rmulu, White, Proc. Roy. Soc. Tasm., 1914, p. 6\%. fig. T. II., White, I'L.S. N.S.W', xli., 1916, р. 97.

Tote--It appears that this insect lias a superficial resemblance to I'urly!gluster whitei, from which it can be distinguish d by the seutellum and the blus-black abdomen.

//uh.-Tasniania. A paratype is in the National Muscum, Mclbourne..

\section{G(nus Evaza, Walker.}

E'm:u, Walker, Proc. Lin. Soe. Lond., i., 185T, p. 109. IIl., Kertesz, Ann. Mus. Nat. Hung, iv., 1906, p. $27 \%$

Type.-Ems lipurs, Walker. ... ... Borneo.

$$
\text { Erazll lipars, Walker. }
$$

Eusu lipur, Malker, Proc. Lin. Soe. Lond., i., 1857, p. 110, Pl. 6, fig. 2. lil, Kertcsz, Anı. Mus. Nat. Hung. iv., 1906, p. 284, Pl. 5, fig. 1.

/lat.--This species was described from Bornco, and reported since from New Guinea and New South Wales.

\section{Genus Wallacea, Doleschal.}

Wallarer. Doleschal, Nat. Tijdschr. Neder.. Ind. (4), iii. (xvii.), 1853, p. 82.

Type.-W"allueen ururuten, Doleschal ... Ambonia.

$$
\text { Willacea duruini, Hill, }
$$

Wallawa tarwini, Hill, P.L.S. N.S.W., xlir, 1919, p. 460, figs. 7 a-c.

\section{Subfam. LopHOTELLINE.}

("luracter. - This subfamily contains species with three posterior veins issuing from the discal cell: the rutellum withont spines; and the last segment of the antennæ ribbon-like.

Iotr.-A single Australian representative was described by Enderiein from a specimcn with broken wings, and the assumption that there are only three posterior 
veins present (i.e., the median is two branched in the terms used by Enderlein) requires. confirmation.

The Australian Museum and the Macleay Museum have, between them, about thirty unidentified specimens, many of which are referable to this and the next subfamily. but unfortunately the specimens in the Australian Museum are not in a suitable condition to be studied with advantage, and those in the Macleay Museum do not seem to belong to the described forms. There is, however, sufficient material with diversity of characters to warrant a special warning against the assumption of venational characters made by Enderlein.

\section{Genus Peratomastix, Fnderlein.}

Prratomasti.r, Enderlein, Zool. Anzeiger, xliii., 1914, p. 311 , fig. 16.

Type.- P'eratomastir austratix, Enderlein. ...... New South Wales.

T'eratomastir austratis, Enderlein.

P'eratomastir austratis, Enderlcin, Zool. Anzeiger, xliii., 1914, p. 311.

\section{Subfam. Hermetinne.}

Churecters.-This subfanily differs from the previous chiefly in the presence of a fourth posterior vein.

Vote.-The material to hand is not in suficient abundauce or in sufficicntly good coudition to enable the snecies represented to be stndied with advantage. Brauer's genus Layenumme is considered to be identical with Walker's genus Massiryten, and although this appcars to be correct further information on the subjoct is desirablc.

\section{Genus Massicyta, Walker.}

Massicutu, Walker, Proc. Lin Soc. Lond., i., 1857, p. 8, Pl. i., fig. 1. Il., Enderlein, Zool. Anz., xliv., 1914, p. $\delta$.

Lagenosmma, Brauer, Denkschr. Akad. Wien., xliv., 1882, p. 81.

Type of Massicyta.-M. Ziculor, Walker ... Singapore. Tvpe of Lagenosoma.-L. pictı, Brauer ... Cape York.

Massicyta picta, Brauer.

Layenosnma pista, Brauer, Denkschr. Akad. Wien., xliv, 1882, p. 81 . 
Masviryta dispar, Brauer.

Lagenosmma dispar, Brauer, Denschr. Akad. Wien., xliv. 1882 , p. 82.

Maswiryto fropinquu, Braucr.

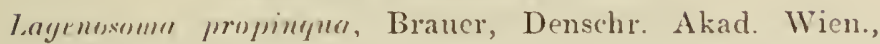
xliv., 1882, p. 82.

Genus Hermetia, Latrielle.

I/ermetio, Latrielle, Hist. Nat. d. Crust. et lns., xiv., 1804, p. 338.

Type-LHermetu illucen:, Latrielle. ... ... America.

Mermetin pullidipes, Hill.

Ilermetion pullielipes, Hill. P.L.S. N.S.W.. xliv, 1919, p. 454 , text figs. $3 \mathrm{a}-\mathrm{b}$.

Eimendurnts:-A letter received from Mr. Hill contains the following note.- "Ro // rmetim prollidipes; I have re-cxamined the type with the following results.-The third joint of the antenne has six amulations visible; what 1 have shown as an outstanding tuft of hairs may arise from a very short and very obscure ammulation (the s(venth), but this could only be ascertained by examination of a balsam preparation. The groove below the same joint covcrs segments 4,5 , and 6 in both sexes. The wing of the male is correctly drawn; in the female there is a space equal to about twice the width of the intermediate vein between it and its junction with the radial vein."

From this it becomes apparent that Mr. Hill's species is placed in its correct genus, and therefore. must not be confused with several closely allied species in various collections which differ in the antennal groove and other particulars.

Fou specimens in the Macleay Museum, from Cape York, also belong to the genus ilermetir. and may be identical with this species.

\section{Subfam. Sargarine.}

Vute-Enderlein renamed this subfamily Grosargurina, but the gensric name was changed on an alleged preoccupation which was not sustained, and consequently the origial subfamily name must be restored.

Ke!l to the dienera of the Sargarina.

1. Scutellum without spines, bright metallic species.

Saryus.

Scutcllum with spines, black species. Asruthasargus. 
Genus Sargus, Fabricius.

Sargns, Fabricius, Suppl. Entomol. Syst., 1798, p. 549. Id., White, P.I.S. N.S.W., x]i., 1916, p. 94.

Type.-Sargus cuprarins, Fabricius ... ... Europe.

Sargus meridionritis, White.

Sargus meridionalis, White, P.L.S. N.S.W., xli.. 1916, p. 95.

Surgus yseili, Hill.

Saryus gselli, Hill, P.L.S. N.S.W., xliv., 1919, p. 459, fig. 6 a-c.

Genus Acanthasargers, White.

Acanthesuryus, White, Proc. Roy. Soc. Tasm., 1914, p. 60. Ir., White, P.L.S. N.S.IV., xli., p. 95.

Type.-Acrenthasargus pallustris, White... Tasmania.

Acumthusurgus pallustris, White.

Acruthasaryis: pallustris, White. Proc. Roy Soc. Tasm., 1914 , p. 60, fig. 6 . I 1 ., White, P.L.S. N.S.W. xli., 1916 , p. 96.

Acrnthasurgus gracilis, White.

Aconthasargus yracilis, White, P.L.S. N.S.W., xli., 1916, p. 98 .

\section{Subfam. Clitellarine.}

Note-Enderlein included the Antissini under this subfamily and created a new tribe Aluvini.

\section{Key to the Tribes of the Clitellarina.}

1. The scutellum without spines.

Ahavini.

The scutellum with spines.

2. The scutcllum with two spines.

The scutellum with four or more spines.

2.

Clitellariini.

Antissini.

\section{Tribu Chitellariini.}

fiey to the Genera of the Clitellarimi.

1. The thorax with a stout spine on each side; the antennæ with a long dense fringed style. Teyritomyia. The thorax without such spines; the antennæ without a fringed style.

2. The antennæ with an arista; the posterior legs with the first joint of the tarsi longer than the tibir.

The antennæ without an arista. 
3. The antennæ very long and slender, about five times the length of the hcad.

Eliswoma.

The antennx not slender, about twice the length of the head.

Uphiorlexman.

Gemus Negritomyil, Bigot.

Migritomyia, Bigot, Ann. Soc. Ent. France (5) vii., Bull. 1877, p. lxxiv.

Ieyrifumyia, Bigot, Ann. Soc. Ent. France (j) iv., 1879, p. 190. Id., White. P.L.S. X.S.W., rli., 1916, p. 82.

(For further references sce liertesz, Cat. Dipt. iii., 1908, p. 16.)

Type-Ephi. prum murnlipemmis, Macpuart. Manilla.

Vryritum!nin allitarsis, Bigot.

Ejhrypium allitaris, Bigot, Anu. Soc. Ent. France (5) ix., 1879, p. 207. Ii., Freceratt, P'L.S. N.S.W., xxi., 1896, p. 84, Pl. ix., figs. 12-13. Id., Froggatt, Arstralian Inscets, $190 \vec{i}$, p. 293.

Vigritumpiu "llitnrsis, White, P.L.s. N.s. IT., sli., 1916, p. 83. Text fig. 4. II., Mill, I'L.S. N.S.W.. xliv., 1919, p. 452. Tryt fig. 2.

IInh.-This is a common species from the northem parts of Anstralia and from $\hat{N}_{\mathrm{C}}$ Guinea. There are seven spucimene in the Macleay Museum from Queensland.

\section{Ginus Geranopes, Mhite.}

Grample, White, P.L.S. N.S.M., xli., 1916, p. S4.

Tyрe-li, mermertus, White. ... ... Victoria.

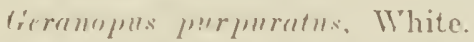

Cirnmopm jmrymrntus, Whit , P.L.S. N.s. IV., xli., 1916, p. S5. Text fige, 5 and 6 .

Genus Eluissnua, White.

Elissoma, White, P.L.S. N.S. W., vli., 1916, p. s6.

Type.-Eliswomm Inutr, Whitc. ... ... Victoria.

Eliswoma lanta. White.

Elissomn lıntu, White, P.L.S. N.S.IT., xli., 1916, p. 87.

Gonus OpHodesul, White.

Ophiodesma, White, P.L.S. N.S. W., xli., 1916, p. 88.

Type--Odontomyin flavipalpis, Macquart. 
Pl. VIII., fig. 1.

Odontomyia flaripalpis, Macquart, Dipt. Exot., suppl. 4, 1850 , p. 49.

Ophiodesma flavipalpis, White, P.L.S. N.S.W., xli., 1916, p. 89. Text fig. 7 .

II $a b$.--Eleven specimens in the Macleay Museum are labelled from Queensland, New South Wales, and Western Australia; the species has already been recorded from Victoria, and therefore it is probable that it will be found throughout the whole of the mainland of Australia. Two specimens, one of each sex, were taken at Blackheath, New South WVales, during November, 1919.

\section{Tribe Abavini.}

\section{Genus Anacanthella, Macquart.}

Anacunthella, Macquart, Dipt. Exot., Suppl. 5, 1855, p. 38. Id., Enderlein, Zool. Anzeiger, xliv., 1914, p. 23. Id., White, P.L.S. N.S.W., xli., 1916, p. 80.

Type.-Anacanthella splendens, Macquart... Adelaide.

Status. - This genus is placed in this position bv Enderlein, who makes interesting though speculative remarks concerning it. No recent specimens of the species are knowll.

Anacanthella splendens, Macquart.

Anacenthella spleudens, Macquart, Dipt. Exot., suppl. 5, 1855, p. 39, Pl. i., fig. 8. Id., White, P.L.S. N.S.W., xli., 1916 , p. 80.

\section{Tribe Antrssini.}

\section{Tey to the Genera of the Antissini.}

1. The scutellum with four or six normal spines; the male with the costa of the wings greatly inflated; the antennie as long as the head.

J.ecomyia. The scutellum with six rudimentary spines; the costa of the wings normal.

2. The antennæ much shorter than the head. The antcnnx twice as long as the head.

Antissa. Antissella.

\section{Gemus Lecomyia, White.}

Lecogaster, White, Proc. Roy. Soc. Tasm., 1914, p. 53 (preoccupied). Id., White, P.L.S. N.S.W., xli, 1916, p. 79. 
Lecomyin, White, Proc. Roy. Soc. Tasnı, 1916. p. 260.

Type-Leroguster cerulen, White ... ... Tasmania.

tote.-This genus is apparently well represented in Australia; there are four undescribed species as well as tho two describud represented in the Macleay Musum.

key to the species of the Cenuss lecomyun.

1. The thcrax bluo; the scutellum normal, lying in the same plane as the thorax; the wings hyaline.

quimquecella.

The thorax black, the seutellum upraised, not lying in tho same plane as the thorax; the wings with a black spot at the middle of the costal margin.

\section{Leremeyin quinquerella, Macquart}

cyания.

Beris quinquectln, Macquart. Dipt. Exot., suppl. 1, 1846 , p. 47, Pl. v., fig. 2. II., Walker, List Dipt. B.M., v. suppl. 1, 1854, p. 12. Id.. White. Proc. Roy soc. Tasm., 1914, p. 49. Il., White, P.L.S. N.S.W., xli., 1916, p. 97.

Lecogfaster corulen, White, Pros. Roy. Soc. Tasm., 1914, p. 54. Text fig. 5. Id., P.L.S. N.S.W., xli., 1916, p. 79.

Siynomymy.- White placed Beris quimunerllu, Macquart, amongst his cloubtful specics, but Mlacruart's illustration was undoubtedly intented to represent this species, as the inflation of the costa, although shown small in the drawing, leaves no doubt concerning the generic position, and the locality given is Tasmania.

Ememlments:-In Macquarts description and illustrations, the scutellum is described with four spines, and correctly illustrated with eight, and the fivo posterior cells described are erronenusly drawn as four. Allowing for these corrertions. Macruart's description and drawins coniom to this species.

\section{J.eromyia ryanen, White.}

Lecoyaster rymen, White, P.L.S. N.S. IT., xli., 1916, p. 79. Text fig. 3.

\section{Genus ANtrssi, Walker.}

Antissu, Walke1, List Dipt. B.M., v. suppl. 1, 1854, p. 63. Id., Brauer, Denkschr. Akad. Weiss. Wien., xliv., 1882, p. T1. Id., Braucr, Offines schr., 1883, p. 7. Id., Osten-Sacken, Berl. Ent. Zeit., xyvi., 1882, p. 373. J木., Fnderlein, Zool. Anzeiger, wliv., 1914, p. 11. Ir., White, P.L.S. N.S.W., 19i6, p. 81.

Type.-Antisw cuprea, Walker ... Western Australia. 
Clitellaria cuprea, Walker, List Dipt. B.M., iii., 1849, p. 524.

Antisal cuprea, Walker, List Dipt. B.M., v. suppl. 1, 1854, p. 63. Id., Braur, Offines schr., 1883, p. 7. Id., White, P.L.S. N.S.W., xli, 1916, p. 81.

Genus Antissella, Walker.

Antissella, Whito, Proc. Roy. Soc. Tasm., 1914, p 52. Text fig. 4. Id., White, P.L.S. N.S.W., xli., 1916, p. 81. Type.-Beris prarvidentuta, Macquart ... Tasmania.

Stotus. - White plaecd the genus Antissella near Antisa, but neither this nor Anacantleella thas been recognised since they were described, and also the descriptions afford insufficient data to settle relationships. The three genera need further study.

\section{Antivsella parvidentata, Macquart.}

Beris parvidentuta, Macquart, Dipt. Exat., suppl. 4, 1894, p. 40 , Pl. iii., fig. 1.

Antisselln purvidentata, White, Proc., Roy. Soc. 'Iasm., 1914 , p. 52. Text fig. 4. Id., White, P.L.S. N.S.W., xli., 1916, p. 81 .

\section{Subfam. Stratiomyine.}

Totes.-The Australian species of this subfamily are placed in one genus, and from their descriptions are liable to be considerably confused. Before new material ean be dealt with much further research is needed, especially with reference to the types. The present study is based upon numerous examples with the intention of finding the limits of species and specific variation, and thus laying the basis for further study on structural rather than colour characters.

Where no structural charaeters have been found to separate snecies undoubtedly distinct, colour characters have been taken into account rather for a guide than for final conclusions. No structural eharacters have been found to separate $O$. carinifaries, Macquart, O. sydneyensis, Sehiner, and some forms of O. deripiens, Guerin, and yet they are apparently distinct species that are found not to merge into each other when long series are examined. $O$. decipiens, Guerin, will be found to comprise a large number of variations, and although many of these at first. sight appear distinct, they cannot be separated when series of considearable length are examined. 
The writer's convictions of the specific value of the various descriptions will be found embodied in the synonymy and the remarks made thereon. Until the types are cramined, and the suggestions made in this work are confirmed or corrected, the identification of the majority of tho species will be unsatisfactory.

\section{Genus Opoxtomyia, Mcigen.}

Enlaliu, Meigen, Nor. Class. 18no, p. 21 (name not permissible). Id., Kertesz, Cat. I)ipt., iii., 1908, 1). 62 (which sec for synonymy).

Odontmmyir, Meigen. Ill. Mag. f. Ins, ii., 1803, p. 265. II., White. Proc. Roy. Soc. Tasm., 1914, p. 55. II., White, P.L.S. N.S.W., vli., 1916, p. 90. Id., Hardy, Proc. Roy. Soc. Ta=m., 1917, p. 61.

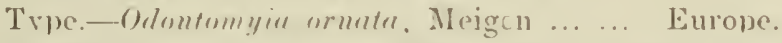

Chervecters. - The species of this genus contain a much depressed five segmented abromen and a scutcllum with two spincs (abcrant specimens in which these spines are absent or deformed are rare and do not excend one in five hundred). The antenna hase the third joint Innger than the two hasal joints mited, and it terminates in a short style. The wings contain four pont rior vein rising from the discal cell.

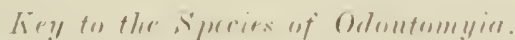

1. The scutcllar spines below (not at the apical margin of) the seutellum and inconspicuous. The antenne have the two hasa! joints united nearly as long as tho third.

"1jurtomert.

The seutellat spines conspicuous and situated at the anical margin of the scut:llum. The antenne with the two basal jointe together much shorter than the third.

2. The sentellar spines vere strong and curved upwards so that they have their apies pointing almost perpendicular to the abdomen.

sintrilutir.

The scutcllar spines normal, thrir avis lying in a blane about parallel to the abdomen.

3. The scutcllar snines long and straight and as wide apart as in Plate VIII., fig. 4. The abdominal sidespots are large, sometimes almost confunnt. generally triangular. The face always black. luferimemulutu.

The scutcllar spines short and cleser tog ther, never wider apart than as illustrated on PI. VIII., fig. 6. If the abdomen has side-spots they are gencrally small, thin, and quadrangular elongate: if the sidespots are large they are generally enfluent. 4. 
4. The abdomen with side-spots.

The abdomen with side margins yellow or green.

5. The face black, gencrally narrowly margined yellow.

The face yellow. carinifacies. sydneyensis.

Note.-O. hunteri, Macleay, and O stricta, Erichson, are not included in the above key; they may be distinct species or varicties, or they may be identical with any of the other species, but no specinens are to hand that can in any way be associated with their respective descriptions. The two species described by Mr. Hill have their scutellar spines inadequatelv described, and therefore their position in relation to the above key cannot be ascertained at present.

Odontomyia scutellata, Macquart.

Pl. VIII., fig. 2 and 3.

Odontomyia scutellatn, Macquart, Dipt. Exot., suppl. 1, 1846, p. 52, Pl. v., fig. 7. Id., White, Proc. Roy. Soc. Tasm., 1914, p. 59. Id., White, P.L.S. N.S.W., xli., 1916, p. 91.

Stratiomyia scutellatr, Walker, List Dipt. B.M., v. suppl1,1854 , p. 55.

Status.- No doubt can exist about the correct identification of this species. White took it just prior to the time lie left Tasmania, but one specimen, in bad preservation, was in the Tasmanian Museum collection; later several isolated specimens were taken, and more recently, when more was known about thcir habits, a long series was obtained.

IIab.-New South Wales, Victoria, and Tasmania.

Odontumyia laterimamelata, Macquart.

P1. VIII., fig. 4.

Odontomyire laterimaculate. Macquart, Dipt. Exot,, suppl. 4, 1850, p. 49. ? Id., White, Proc. Rov. Soc. Tasm., 1914 , p. 58 (male only). ? Id., White, P.L.S. N.S.W., xli., 1916, p. 94 (male only).

Status.-White's identification of this species requires confirmation. White identified it as the larger of two similar species, both of which occur in Tasmania as well as on the mainland of Australia. The two species, O. carinifaries, Macquart, from Tasmania, and O. laterimaculata, Macquart, from Australia, are not to be separated by Macquart's descriptions; both are described from the male, 
and tho typical male of $O$. corinifnries, Macnuart, as identified by ilhite, is not replesented in any recent. collection from the type lccality, and this suggests that White transposed tho name, if indect Macquart's spccies are really distinct. The key to the solution lies in the fact that White's 0. Intrimmulutn, male, has the scutellar spines wider apart and longer than in those identified by White as O. cormifucies. An eramination of the structure of Macquart's types wil! easily detcrmine if $\mathbb{W}^{\circ}$ hite transposed the names.

The specimen identified by White as O. Interimmentutn, female, is not the fomale of his malf, as the species has been taken in copula on several occasions in Tasmania. On this account Whites female is refered to O. sylueyrnsis, Schiner, as the description conforms to that specics, nevertheless the form has not been seen by me from that State.

/Kah.-Tasmania, Victoria and New Sou:h Wales.

Type.-The male spromen upon which White identified the species is in the Australian Muscum.

\section{Olonfumyin rerinifuries, Macquart.}

I']. VIII., fig. 5.

OAm'mmyiu rurinifuries, Macquant. Dipt. Exot. Suppl. 4, 1850, 1. j1. ! I/. White, Proc. Roy. Soc. Tasm., [9]4, p. 5T. ! I,., White, T.L.S. N.S.W., xli., 1916. 1).94.

S'ufus.- White identified this as the smalle of two similar specis, but Macquart's description is not to be separated frem (). lutermurulutu, Maçuart, under which specics further remarks are supplied.

The trpical male of the species id ntified by White is not known in recent collections, but a mountain form described below as a varicty is mueh smaller and has the male with the colour patterin similar to that of the female.

The only male that can be associated with the typical form lias a distinctive colour pattcrn, and is described, apparently for the first time, und $x^{\circ}$ the second variety name below.

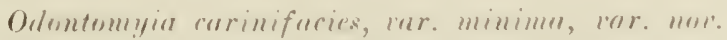

\section{Pl. VIII., fig. 7 .}

Jescription.- $\Lambda$ small mountain varicty of (). cariwifuries (as identified by White) oceurs on Mt. Wellington, Hobart. Tasmania, at alout the altitude of 2,000it. The males aro common and the females scarce, and on two occasions specimens have been taken in copula. 
The abromen is shorter and more compact than in the typical form, and is illustrated on Pl. VIII., fig. 7, which figure was drawn from the holotype var.

Length never exceeding $8 \mathrm{~mm}$., and averaging $7 \frac{1}{2} \mathrm{~mm}$.

Odontomyia carinifacies, var. grandimaculata, war. nor.

Pl. VIIl., fig. 6.

Status.-A male of average size, but remarkably different in colour and spots on the abdomen, taken in abundance with the typical females, is here given a special form name. It is possible that this varicty represents a distinct species, but without a female of the varicty or a male of the typical form it is not advisable to separate them.

Desrriftion.-The abdomen and scutellum are illustrated on Pl. VIII., fig. 6 ; the abdomen is black with large reddish confluent or almost confluent side-spots which are generally confluent on the extrome lateral edges. In other respects the variety is similar to the typical form, but the legs may be black or reddish, or may contain both these colours.

\section{Leng!h.-8-10 mm.}

IIrel,-CTasmania: Bream Creek, February, 1918, 36 specimens; Garden Island Cresk, Dccember, 1916, 1 specimen; Lymington, December, 1916, 3 specimens.

South Australia: Two specimens in the Macleay Muscum are labelled from this State and conform to the variety.

Tinte-Four stray specimens were taken at Lymington and Garden Island Creek, and later specimens were met with in large quantitios at Bream Creek, where large series of the male variety and of the female typical form were taken. A second visit was made to Bream Creek for the purpose of securing a pair in copula and thus definitely ascsrtaining the sex relationship, but unfortunately the weather turned clovdy and the object of the trip was not attained, but a second and longer series of the two forms was taken.

Odontomyia systumensis, Schiner.

Odontomyia sydneyensi., Schiner, Nov. Reise, Dipt., 1868, p. 60.

? Odontomyia laterimaculata, \& White, Proc. Roy. Soc. Tasm., 1914, p. 58. ? Id., White, P.L.S. N.S.W., xli., 1916, p. 94.

Synonymy-O. Iaterimarulata, Macquart (as identified by White), has been taken in copula on several occasions 
in Tasmania, and the female las invariably a black face and front. not fulvous, and is as large as the male. A smaller specimen with a yellow face and front is not represented in many collections, but conforms to the descrintion of O. syduryensis, Schiner, and White's female record of (). letrrimarnlutu prebably belongs here, but donbt. must he placed upon its identity with (). syduryensis. Schiner, as this spccies is not represented from 'Tasmania in any collection.

Stotus-This species, described by Schiner, was entircly overlcoked by White, and the remark under the description given by Sehincr to the effect that it secms to be related to (). Ioterimurmlom, Macquart, suggests that tho

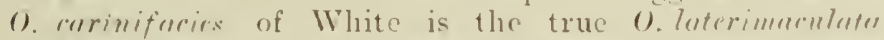
of Macquart Until the status of cach of these various species is inquired into and established by eximnination of tho type material the determination of the species of the Odmulmmyin in Australia will remain unsatisfactory.

IInl,-New scuth Wales, Sydney.

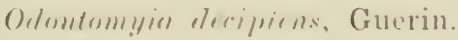

$$
\text { Pl. VIII., fig. \& and } 9 .
$$

Oryerre deripurn, Guerin, Voy. Coq. zool. 2, ii.. 1830. p. 291.

Mrrmem! Ireipirax, Kertesz, Cat. Dipt. iii., 1908, p. 33.

Odememyen renisyemeryii, Macquart, Dipt. Exot. i., 1, 1835, p. 186. II.. White, P.L.S. N...W., xli, 1916, pl). 90 and 100.

Strmtiom!ls retgismem!gi, Walker, List. Dipt. B.M., v. suppl. 1, 1854, p. 56.

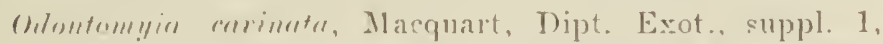
1816, p. 52. Ir., White, Pror. Roy. Soc. Tarm., 1914, p. 59 ; and 1910, p. 260. 1,., White, P.L.S. N.s.W., xli., 1916, p. 90.

Sitrmimm!s corimuln. Walker, List. Dipt. B.M., v. suppl. 1, 18.5. p1. .36 and 312.

Oflonfemyin sfylefr, Macquart, Dipt. Exot., supul. 2, 1847, p. 30: and :uppl. 4, 1850, p. 52. Id.. Froggati, Iustralian Insects, 1907, p. 294. Id., White, Proc. Roy. Soc. Tasm., 1914, p. 56. Id., White, P.L.S. N.S.W ., xli., 1916, p. 90.

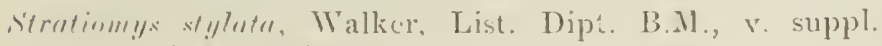
1. $18 . \%$. 1. 56. 
Odontomyia iulemus, Walker, List Dipt. B.M., iii., 1849, p. 535. Id., Bigot, Ann. Soc. Ent. France (5), ix., 1879 , p. 186 . Id., White, P.L.S. N.S.W., xli., 1916, p. 90.

Stratiomys inlemus, Walker, List. Dipt. B.M., v. suppl. 1, 1851, pp. 54 and 312 .

Odontomyia amyris, Walker, List. Dipt. B.M., iii., 1849 , p. 535. Id., White, Proc. Roy. Soc. Tasm., 1914, p. 56. Id., White, P.L.S. N.S.W., xli., 1916, p. 91. Ill, Hardy, Proc. Roy. Soc. Tasm., 1917, p. 62.

Odontomia subdentata, Macquart, Dipt. Exot., suppl. 4, 1850), p. 49. Ir., White, Proc. Roy. Soc. Tasm., 1916 , p. $260 . \quad$ Id., White, P.L.S. N.S.W., xli., 1916, p. 92. Id., Hardy, Proc. Roy. Soc. Tasm.. 1917 , p. 62.

Odontomyin rufifacies, Macquart, Dipt. Exot,, suppl. 4, 1850, p. 51. Id., White, Proc. Roy. Soc. Tasm., 1914, pp. 55, 56, and 74 . Id., White, P.L.S. N.S.W., 1916, p. 90.

Odontomuia marginella, Macquart, Dipt. Exot., suppl. 4, 1850, p. 52. Id., White, Proc. Roy. Soc. Tasm., 1914, p. 57 ; and 1916, p. 260. Id., White, P.L.S. N.S.W., xli., 1916, p. 93.

Odontomyid anmulipes, Macquart, Dipt. Evot., suppl. 4, 1850, n. 52. Id., White, P.L.S. N.S.W. xli., 1916 , pp. 90 and 92.

Odontomyia pricea, Walker, Ins. Saund. Dipt. i., 1850, p. 78. It., White, P.L.S. N.S.W., xli., 1916, pp. 90 and 100 .

Stratiomys picen, Walker, List. Dipt. B.M., v. suppl. 1, 1854 , p. 55.

Odontomyia Firchneri, Jaenuicke, Abh. Senck. Nat. Ges., vi., 1867, p. 323.

Odontomyia pectoralis, Thomson, Eug. Resa, Dipt., 1869, p. 455.

Synonymy.-The above synonymy includes all descriptions that come within the probable variation of the common and widely dispersed species of Odontomyia previously known as $O$. amyris, Walker. When the types are examined together with a long series of new specimens, 
this long list mav be found to contain more than one species.

The scutcllar spines of this specics are identical with those of $O$. corinifarifs, Macquart, and $O$. sydmeyensis, Schiner, in the larger specimens, but smaller and distinctive spines are to be found in small specimens, and these range in size to normal spines, making it impossible to form specific differences on this character.

Traces of a tibial ring. often met with in other species, appear rare in $O$. Arripirns. Guerin, and no value can bo placed on this or the face colouration for identification purposes.

Guerin's description of $O$. deripiens is typical of the male described by White as $O$. mmyris, Walker. There can te littlo doubt that it is correctly identified.

O. reyisyporyii, Macquart, is described from a mutilated specimen, and probably belongs here.

O. sululunfutu, Macquart, probably belongs here, and White's record for Tasmania certainly bolongs here, but a specimen with the black carina described by Macquart is not known in any recent collection.

O. rufifuries, Macquart, undoubtedly belongs here.

O. muryinelle, Macquart, reads like that of O. opertamen, White, and differs clicfly in tho underside of the abdumen and the legs. The black face makes it somewhat doubtful if the species is correctly placed here, but the "Thorax with light green reflections and ycllow pile" and the "Srutellum with little spines" prevent it being identified with any of the othcr species known.

(). Innulipes. Macquart, is distinctive in the two sexes, the malo (like $O$. mreryimelln, Macquart) reads similal to Whiteis $O$. oprermen, and indeed may be identical with it, but the female is referable to the form described under the name (). amyris, Walker, by myself in 1917.

O. piren, Walker, apparently belongs here. White stated that the trpe in the British Muscum is in too bad a condition for determination.

O. lierchneri. Jaennicke, and O. pectoralis, Thomson, were overlooked by White. Their descriptions conform to that of $O$. Arcipiens, Guerin. 
Odontomyia opertanea, White.

Text figs. 5, 6, and 7 .
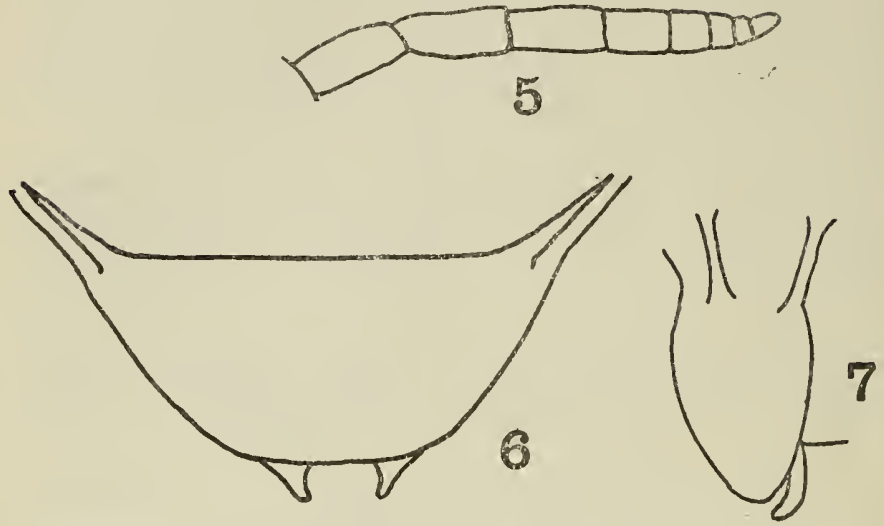

Odontomyia opertnnea, Wlite, P.I.S. N.S.W., xli., 1916 , p. 93. Id., Hardy, Proc. Roy. Soc. Tasm., 1917, ค. 62 .

Stratus.-I am indebted to Mr. C. E. Cole for the loan of a specimen of this species ircm Ringwood, Victoria, and this is identical with the Tasmanian speciniens recorded in 1917 .

Description.-The following description is taken from the Tasmanian specimens, and is supplementary to White's description :-

Female. The antennæ are longer than in the other Australian species; the two basal joints are equal, and together are almost as long as the third. The scutellar spines are small, inconspicuous, and placed under the scutellum instead of on the apical border.

It is a black species with slight tracings of golden tomentum on the head and the thorax, a small yellowish area round the oral opening, the legs and wing veins yellowish, the abdomen green ventrally, and dorsally bordered very narrowly green, which colour shows signs of turning yeilow in places, in addition to which there is a pair of very small lateral spots confluent with the border on the 2nd, $3 r d$ id 4 th segments, and the apex of the halteres green.

Length.-7-8.5 $\mathrm{mm}$.

Hab.-Tasmania: Cradle Mountain, two females, 17th January, 1917. Victoria: Ringwood, one female. New South Wales: Blue Mountains, one female in the Macleay 
Muscum. Wcstern Australia: King George Sound, two femalcs in the Macleay Muscum.

Orloutrmyin jumbsta. Hill.

Odontrmygin prellieln, Hill, P.L.S. N.S.IV., xliv., 1919, p. 456. Text figs. 4 a-b.

Sintus.-It is impossible without a proper description of the scutellar spines to ascertain if the relationship of this species is near (I. Aerifurns, Guerin, which seems probable, as there is nothing in the description to separate it froni that variable species.

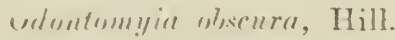

Odontrm!nin usenre, Hill, P.L.S. N.S.W., xliv., 1919, p. 457. Text fig. 5 a-b.

Situtus-The illustration of this specics conforms to (). laterimurnlatu, Macquart, and indecd the description reads remarkably similar to a variation of the same, but differs in some colour markings.

It is pos-ible that this may be the long missing 0 . luntrri, Macleav, which probably came from somcwhere on the northern coast of Australia, and also appcars to conform to O. leterimuruls'n, Macquart.

\section{Odontomyin lumteri, Macleay.}

Stratium!ys liunteri, Macleay, in King's Narr. Surv. Austr. ii., 1827, p. 467 .

Odontrmyin lunteri, White. P.L.S. N.S.W., sli., 1916, p. 92.

Statu:- The type of this speries apparently cannot be traced. A specimen corresponding to the description is net to be found in the Australian Muse 11 m nor the Macleay Muscum, and it is advisable to hold over the identification until more material is arailable.

It could be O. Interimurulnta, Macquart (as identified by White), which sometimes has only two basal pairs of spots present. White included the reference under his (). "In!y ris, Walker, now O. drripirns, Gucrin, stating that a rare form has two pairs of spots, but as no special colour is given for the face in the original description this would probably be black and not yellow.

The description of $O$. wissuru, Hill, also conforms to tho O. Interimarulutn variety referred to above, and as Macleay's species probably came from somewhere on the northern coast of Australia it is possible that $O$. obscura, Hill, belongs here. 
Odontomyia stricta, Erichson.

Odontomyia stricta, Erichson, Arch. f. Naturf., viii., i., 1842, p. 272. Id., White, P.L.S. N.S.W., xli., 1916 , pp. 90 and 100.

Stratiomys stricta, Walker, List. Dipt. B.M., v. suppl. 1,1854 , v. 55 .

Status.-This description appears confused, and no specimen is known to agree with it. Possibly the description was taken from more than one species, which would account for the apparent mixture of characters.

\section{Strationyia badius, Walker.}

Stratiomys badins, Walker, List. Dipt. B.M., iii., 1849, p. 529 ; and iv., 1849 , p. 1157. 1d., White, P.L.S. N.S.W., xli., 1916, p. vo and 100.

Hab.-Walker first gave New Holland as the locality, and then changed it to New Hudson. This species is cancelled from the Australian list.

\section{BIBLIOGRAPHI.}

This list contains works clealing with Taxonomic Entomology only. and it is confined to works dealing with Australian Entomology and such other works that contain the original descriptions of genera.

Bigot, Paris.-Société Entomologique de France, series: 5, Vol. vii., Bulletin, 1877; and Vol. ix., 1879.

Braner, Viemna.-Kaiserliche Akademie der Wissenschaften. Denkschriften, xliv., 1882.

Offenes Schreiben als Antwort auf Herrn Baron Osten-Sacken's "Critical Review" meiner Arbeit iiber die Notacanthen. (Wien. 1883, Published by the author, 11 pages; a controversial pamphlet.)

Doleschal, Naturrkundig Tijdschrift voor Nederlandsch Indie, etc., series 4, Vol. iii. (= Vol. rvii.), 1858.

Enderlein, Zoologischer Anzeiger, xlii., 1913; and xliii., 1914 ; and xliv., 1914.

Erichson, Archiv fuer Naturgeschichte, viii., part 1, 1842. Fabricius, Supplimentum Entomologia systematica, 1798. Froggatt, Proceedings of the Linnean Society of New South Wales, xxi., 1896.

Australian Insects, 1907 .

Guérin-Méneville, Voyage autre du Monde sur la Coquille pendant Zoologic, Vol. ii., 1826-30. (1831.)

Hardy, Papers and Proceodings of the Royal Society of Tasmania, 1917. 
Hill, Iroccedings of the Linncan Society of New South Wales, xliv.. 1919.

Jaennicke, Frankfort on the Main.-Senckenbergische Naturforschende Geselischaft. Abhandlungen, vi., $186 \overline{1}$.

Kertesz. Budapest.-Museum Nationalis Hungarici, Annales IIistorico-Nationales (Magyar Nemzeti Múzeum, Természetrajzi osztalyainak Folyoirata) iv., 1906 .

Museum Nationale Hungaricum. Catalogus Dipterorum, hucusque descriptorum, iii., 1908.

Kirby, Annals and Magazine of Natural History, serios 5, Vol. xiii., 1884.

Latrielle. Ifistoric naturclle des Ciustacos et des Inscetes, ctc. Vol, xiv., 1804 (forming part of Buffon.- Hist. Nat.-new cdition-edited by C. S. Sonnini. 17991805.)

Loew, Stettin.-Entomologische Zcitung. Herausgegeben. von dem..... Vereine vii., 1S46.

Macquart, Diptères exotiques nouveaux ou peu connus. 2 tom. and suppl. 1-5. (Reprinted from the Mémoires Société Royale des Sricnces de l'Agriculturo et Arts, Lillc.) 18338-1854.

Maclear. in King's Narrative of a survey of the intertropical and Western Coasts of Australia. Vol. ii., Appendix, Amulosa, 1827.

Meigen, Klassifikizion und Boschreibung der Europäischen zweifligeligen Insekten. Tom. i, 1804.

Illiger's Magazine fuer Inscktenkunde, ii., 1803.

Nouvelle classification des Mouches à deux ailes (Diptera) d'apres unc plan tout nouveau, 1800.

-) sten-Sacken, Berlin.-Entomologischer Vercin. Berliner Entomologische Zeitschrift. Vol. xxvi., 182z, and xxvii., 1823.

Catalogue of the North American Diptera, second edition (Smithsonian Institute.-Smithsonian Miscellancous collections. Vol. xri., No. 2), 1878.

śchiner, Vienna. - Kaiserlich-Koenigliche ZoologischBotanische Gescllschaft. Verhandlungen, xvii, 1867.

Austria-Hungary--Reise rler Fregatte Novara, 1857 59. Zoologischer Theil. Bd. ii., Diptera, 1868. 
Thomson, Sweden.-Kongliga Svenska Fregatten Eugenies Resa, ctc., ii., Zool. part 12, Dipt., 1869.

Walker, List of the Dipterous Insects in the British Museum. Vol. 1, 1848; Vols. 3 and 4, 1849; and Vol. 5, suppl. 1, 1854.

Proceedings of the Linnean Society of London, Vol. $1,1857$.

Insecta Saundersiana. Vol. 1, Diptera, 1850-1856 (part of Saunder' Insecta Saundersiana, 1850-1859.)

White, Papers and Prccedings of the Royal Society of Tasmania, 1914 and 1916.

Proceedings of the Linnean Society of New South Wales, Vol. xli., 1916.

Wiedemann, Ausscrcuropäische zweiflugelige Insekten, ii., 1830.

Williston, Transactions of the Entomological Society of Philadelphia, Vol. xv., 1888.

\section{EXPLANATION OF PLATE.}

Fig. 1. Scutellum of Ophiorlesma favipalpis, Macquart.

Fig. 2. Scutellum of Orlontomyin scutellata, Macquart, dorsal view.

Fig. 3. Scutellum of Odontomyia scutellate, Macquart, lateral view.

Fig. 4. Scutellum of Oclontomyia laterimaculata, Macquart.

Fig. 5. Scutellum of Ortontomyia carinifacies, Macquart, Q typical form.

Fig. 6. Scutellum of Odontomyia carinifacies var. grandimaculata, var. nov.

Fig. 6. Abdomen and scutellum of Odontomyia carinifacies var. grandimamlata, var. nov.

F:g. 7. Abdomen and scutellum of Odontomyia carinifacies var. minima, var. nov.

Fig. 8. Abdomen and scutellum of Odontomyin decipiens, Guerin, drawn from a small specimen.

Fig. 9. Abdomen and scutellum of Odontomyia decipiens, Guerin, drawn from a second small specimen.

Note.-All the above illustrations were drawn to the same scale. 


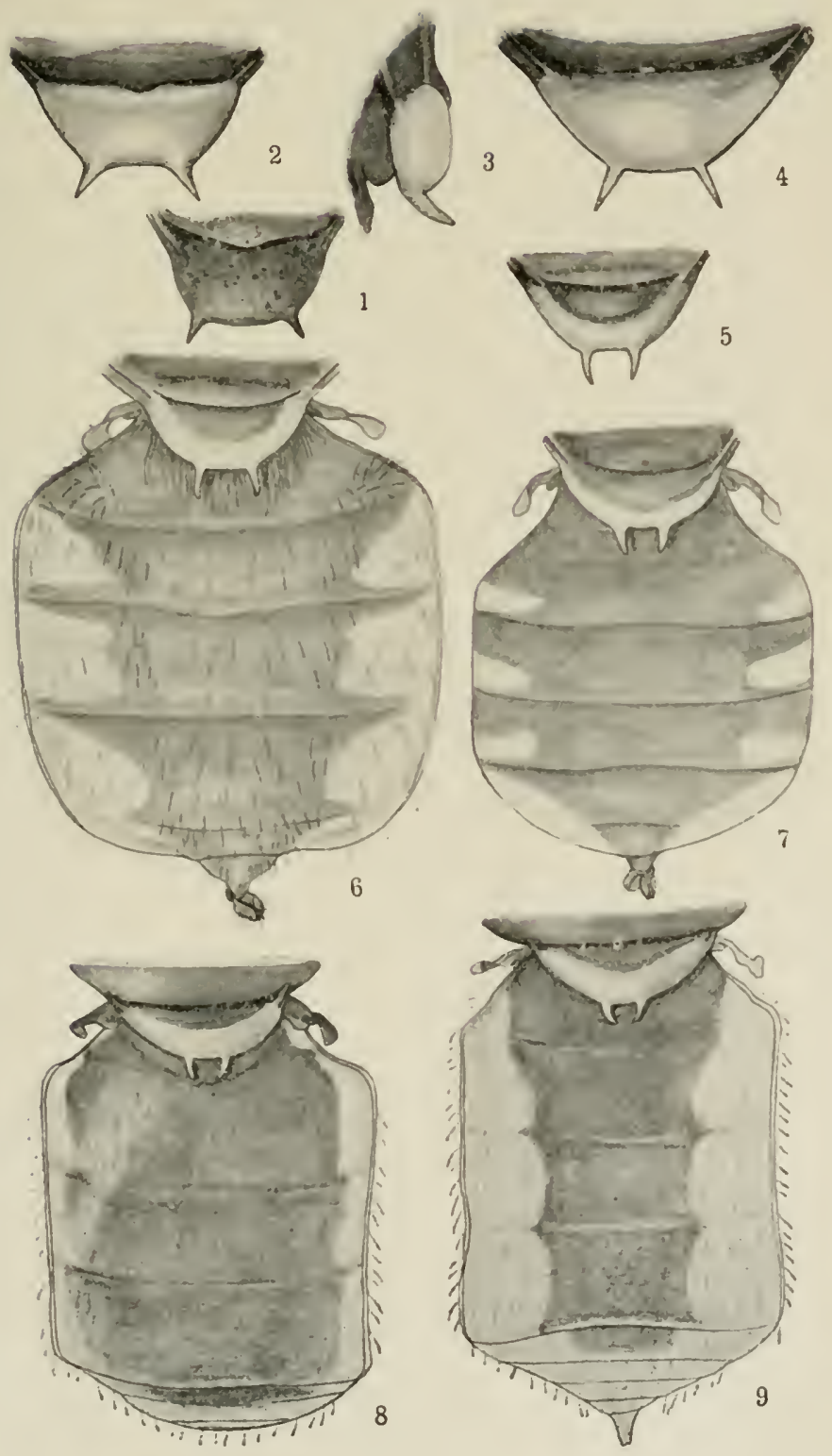

